\title{
The Effect of Financial Performance on Capital Expenditure and Economic Growth of Districts / Cities in North Maluku Province
}

\author{
Hermawan Supriyanto Hartaty Hadady Suwito \\ Management Study Program, Local Financial Management Concentration, Khairun University, Ternate
}

\begin{abstract}
This study aims to examine the effect of financial performance on capital expenditure and economic growth in regency / city of North Maluku Province. The population was all districts and cities in North Maluku Province. Sampling was done by saturated sample method to 10 districts and cities in province of North Maluku. The research uses secondary data from Budget Realization Report 2016-2019 of audited Local Government Financial Statements by Republic of Indonesia Financial Audit Board. The research hypothesis was tested using Partial Least Square (PLS) analysis. This study results shows that financial performance affects on capital expenditures allocation, financial performance affects on economic growth, capital expenditures affect on economic growth, and financial performance affects on economic growth in districts / cities of North Maluku Province in 2016 - 2019 through the capital expenditures allocation. All the research results above can be proven at $\mathrm{t}$ count $>\mathrm{t}$ table and a significance value that is lower than 0.05 .
\end{abstract}

Keywords: Financial Performance, Capital Expenditures, Economic Growth.

DOI: $10.7176 / \mathrm{PPAR} / 11-3-03$

Publication date: April $30^{\text {th }} 2021$

\section{INTRODUCTION}

The financial performance measurement is needed to the condition of financial management (Kaeng, AR 2015). Halim (2013) stated that financial performance was the achievement level of a target for local government financial activities. This level of achievement is measured through financial indicators which can be assessed from results of accountability for implementation of Local Revenue and Expenditure Budget (APBD). Financial capability is the conformity of results of financial performance with the planned targets. The financial ratios used to analyze government financial performance include four ratios of (1) Local Financial Independence Ratio, (2) local revenue (PAD) Effectiveness Ratio, (3) Local Financial Efficiency Ratio. In addition, measurement of financial performance at local governments can also be used to assess the accountability and financial capacity of regions in implementing local autonomy (Mardiasmo, 2009).

The financial capacity to finance the implementation of local autonomy shows the financial performance of region. Performance measurement is done by financial ratio analysis. Saputra (2014) stated that financial ratio analysis was done by comparing the results between periods to find the trend. Local financial performance is good if the region has a high level of independence to create adequate capital expenditures.

Capital expenditure illustrates the efforts of local governments to increase local development. Local governments need to provide a larger share of capital expenditure in composition of local expenditure to encourage local development and economic growth. Capital expenditure, also known as development expenditure, has a positive and significant impact on economic growth. Priyo Hari Adi (2006) stated that economic growth is determined by local development expenditure factors. The development of infrastructure and public facilities can improve the services quality to community and can attract investors. This can provide opportunities to increase local per-capita income and can promote economic growth. Greater capital expenditures allocation means government more serious to develop the region and making the people prosperous. However, the composition of expenditure is still dominated by operational expenditure, especially personnel expenditure.

The local government's ability to make capital expenditures depends on a region's ability to achieve revenue targets or effectiveness. The local government can make capital expenditures as budgeted without deductions if the revenue target is achieved. The ratio of effectiveness is measured by comparing the amount of realized PAD and PAD target which is calculated based on allocation of PAD for the year. The region is effective if the amount of realized revenue is higher than the target set.

Local governments will get more funds to increase capital expenditure for the financial efficiency achievement. Local financial efficiency ratio is measured by comparing total local expenditure with total local income. A region is efficient if the local expenditure is small and total income is high.

Todaro (2003) in Sasana (2009) mentioned three factors of the country economic growth, namely capital accumulation, population growth and technological progress. Capital accumulation is closely related to investment. One progress of a region can be shown by good economic growth, one factor that influence economic growth is the local government investment. The local financial capacity must adequate in order to increase investment. The indicator for local investment size is the high ratio of capital expenditures in 
APBD. The capital expenditures allocation to local governments is influenced by local financial performance condition. Therefore, there is a relationship between local economic growth and capital expenditures allocation and financial performance.

Adi (2007) stated that economic growth has been largely determined by local development expenditure factors. This was consistent with opinion of Kuncoro (2004) that construction of facilities and infrastructure by local governments has a positive effect on economic growth. Hamzah (2008) stated that economic growth of a region is influenced by financial performance of local government. The independence ratio and compatibility ratio have a significant and positive effect on economic growth, while the effectiveness ratio does not have a significant effect on economic growth. Harianto and Adi (2007) stated that local revenue has an effect on economic growth. Kawa (2011) stated that local independence ratio, PAD effectiveness ratio, and budget efficiency ratio do not have a significant effect on economic growth, operating expenditure compatibility ratio and capital expenditure compatibility ratio have a significant positive effect on economic growth.

The local government role in finances management is critical for the success to increase the economic growth in a region. The good local financial governance, including the appropriate allocation of capital expenditures, will have an impact on economic growth in the area. Therefore, researchers are interested to examine the effect of financial performance on capital expenditures allocation and economic growth.

\section{LITERATURE REVIEW}

\section{Local Financial Performance}

Sijabat (2013) defined financial performance as the target achievement of local government activity measured by financial indicators that can be assessed from results of accountability for implementation of Local Revenue and Expenditure Budget (APBD). Sumarjo (2010) stated the financial performance of local governments is the output or result of activities or programs that will be or have been achieved in connection with the use of local budgets with measurable quantity and quality. Local capability can be measured by assessing the efficiency of services provided to community.

Syamsi (1986) stated that the financial performance of local governments is the ability of a region to explore and managing the local financial sources in fulfilling their needs to support the government system, service to community, and local development without fully depending on central government and having the flexibility to use funds for benefit of local community within limits stipulated by laws and regulations. Therefore, it can be concluded that Local Government Financial Performance is the level of achievement of a work result in local financial sector which includes the budget and budget realization with the use financial indicators that are determined through a policy or statutory provisions during the budget period.

Fahmi (2012) defined financial performance as the result or measure of an analysis done to see how organization has done its activities by using proper and correct financial implementation rules. The definition of financial performance according to Jumingan (2006: 239) is a description of organization's financial condition in a certain period which is usually measured by indicators of capital adequacy, liquidity and company profitability.

\section{Capital Expenditure}

Capital expenditures are investments in form of procurement / purchase of assets with benefit more than 12 months and these assets are used in government activities that have economic, social and other benefits to increase the government's ability to serve the community. Thus, capital expenditure is useful to improve the welfare of community (Badrudin, 2012).

Based on Minister of Home Affairs Regulation No. 59 of 2007 article 53 (the first amendment of Permendagri No.13 / 2006) stated that capital expenditures are used for expenditures made in context of procuring tangible fixed assets that have a useful value of more than 12 months in government activities. The value of intangible fixed assets in capital expenditure budget is the purchase price / building of asset plus all expenditures related to procurement / construction of asset until the asset is ready to use. Halim (2008: 65) stated that capital expenditure is budget expenditure for acquisition of fixed assets and other assets that provide benefits for more than one accounting period. According to Mardiasmo (2009: 42) "Capital expenditure is expenditure whose benefits tends to exceed one fiscal year and will add to routine budget for operational and maintenance costs".

Capital expenditures are closely related to investments made by local governments. Halim (2008: 67) stated that word investment can be interpreted in various ways depending on the interpretation context. The macroeconomics investment can be interpreted differently from language of microeconomics, and can also be different from language of accounting. The accounting in context of types of expenditures / expenses, investment can be raised from difference between revenue expenditure and capital expenditure. Investment, including in definition of capital expenditure is defined as expenditure / expense / expense that provides benefits for more than one year.

Based on description above, it can be concluded that Capital Expenditures are expenditures originating from 
a budget in local government which are used to obtain fixed assets that can provide benefits for more than one accounting period and are used by local governments to do public service duties with hope that they can impact growth economy in future.

\section{Economic growth}

The economic growth can be interpreted as a development to produce goods and services in society to increase the community prosperity. Todaro (1997) in Adi (2007) specifically stated three main factors or components of economic growth, namely capital accumulation, population growth and factors related to workforce increase which positively stimulate the economic growth.

Sukirno (2011) stated that economic growth was a quantitative measure that describes the development of an economy in a certain year compared to previous year. Boediono (1994) stated that economic growth is a long-term per capita output growth process that occurs when there is an increase in output originating from internal processes of economy itself and temporary. In other words, this growth is self-generating, which produces strength or momentum for continuity of economic growth in the next period.

Economic growth shows about how economic activity will generate additional public income in a certain period. Economic activity is the process to use production factors in form of capital and labor to produce output. All economic activity in a certain time period is calculated in a money value summarized in Gross Domestic Product (GDP), or in other words, GDP is the value of all goods and services produced in a country in a certain period (Dornbusch et. al., 2001).

GRDP is an important indicator to determine economic conditions in an area in a certain period, both at current prices and at constant prices. The calculation of Gross Local Domestic Product conceptually uses three kinds of approaches, namely: Production, Expenditure and Income Approach.

\section{Research Conceptual}

The condition of Local Government independence has not shown significant progress. Utomo (2012) in Suwandi and Afrizal (2015) indicated that regions are not serious to optimize their potential, by relying more on receiving General Fund (DAU) in form of grants. As a practical consideration, this effort is preferred that significantly increase the PAD.

The PAD effectiveness ratio shows the level of local capacity in realizing the targeted PAD based on real potential of region. The ability of a region to do its duties is said to be effective if the ratio achieved is 1 or 100 percent. Higher ratio of effectiveness improves the capacity of the region. The higher ability of regions to realize the targeted PAD, more they can meet the needs for development expenditure to increase local economic growth (Sularso and Restianto, 2011).

The fiscal decentralization should make each region can manage their local finances effectively and efficiently. The local expenditure smaller than the local income, shows the region can is efficient the local finances. The smaller the efficiency value means the more efficient the region and indicates that expenditures are spent as planned. The region should also affect on value of its capital expenditure allocation as a form of local development.

The Expenditure compatibility ratio is an illustration of how local governments prioritize their allocation of funds for routine expenditure and development expenditure optimally. The higher percentage of funds allocated for routine expenditures means that percentage of investment expenditure used to provide economic facilities and infrastructure for community tends is smaller.

Local financial performance is a reflection of local capacity in managing local finances. Good financial performance illustrates that local governments can manage their finances well, explore the potential of regions that generate maximum PAD so as to create the independence of Local Government in accordance with objectives of local autonomy. Local governments with improved financial performance are also expected to have an impact on increasing the Capital Expenditure Allocation as a reflection of local development. Gerungan, et al (2015) found that simultaneously the variables of Local Financial Independence, Local Financial Dependence, PAD Effectiveness, Capital Expenditure Effectiveness, Efficiency, and Consistent Expenditures have a significant effect on Capital Expenditure Allocation.

Tiara (2016) showed that local financial performance affects on capital expenditure, capital expenditure affects on economic growth, and indirectly financial performance affects on economic growth. Based on above arguments, the research framework as follows. 


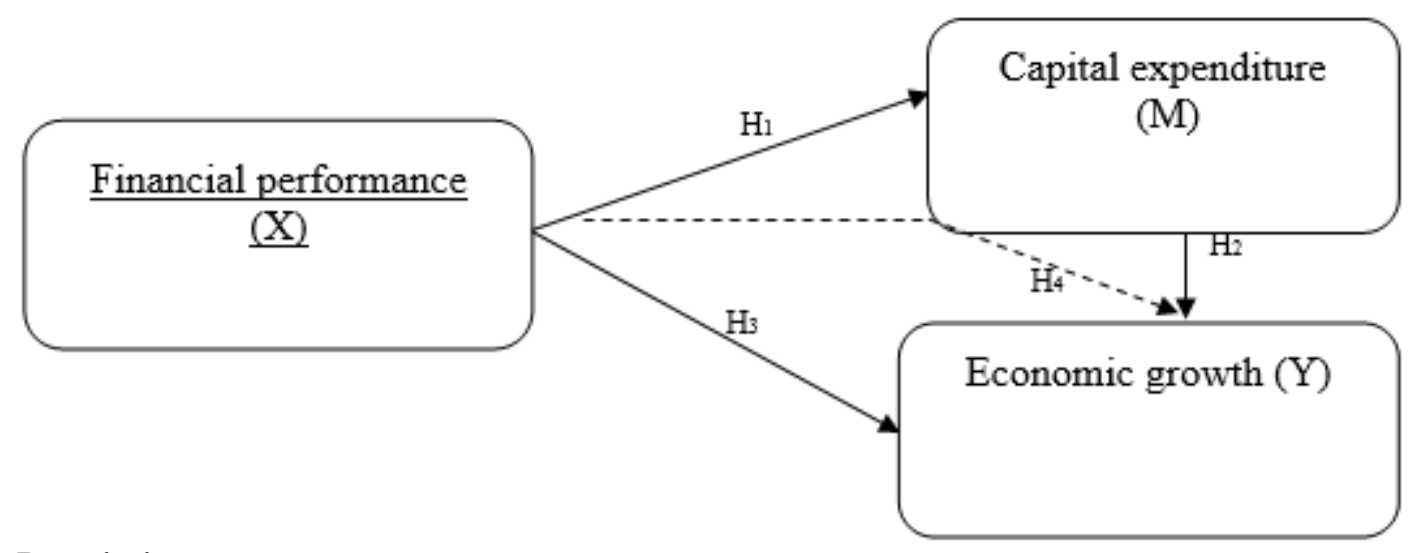

Description:

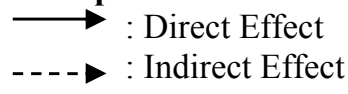

Figure 1. Research Framework

\section{Hypothesis}

Regional financial performance is a reflection of the regional capacity to manage the regional finances. Good financial performance illustrates that local governments can manage their finances well. Local governments with improved financial performance should have an impact to increase the Capital Expenditure Allocation as a reflection of regional development. Gerungan et al. (2015) found that simultaneously the regional financial independence, regional financial dependence, PAD effectiveness, capital expenditure effectiveness, efficiency, and consistent expenditures have a significant effect on capital expenditure allocation.

Tiara (2016) showed that regional financial performance affects on capital expenditure, capital expenditure affects on economic growth, and indirectly financial performance affects on economic growth. Based on these arguments, hypothesis is formulated below.

H1: Financial performance affects on capital expenditure.

Todaro (1997) in Adi (2007) specifically mentioned three main components of economic growth, namely capital accumulation, population growth and factors related to workforce increase that positively stimulating economic growth. Adi (2007) stated that economic growth has been largely determined by local development expenditure factors.

Kuncoro (2004) stated construction of facilities and infrastructure by local governments has a positive effect on economic growth. Increasing public sector services in a sustainable manner will improve public facilities and infrastructure, government investment also includes improvements to education, health and other supporting facilities. Based on these arguments, hypothesis is formulated below.

$\mathrm{H} 2$ : Capital expenditure affects on economic growth

The self-reliance ratio illustrates the dependence of a region on external sources of funds. The self-reliance ratio also describes the level of community participation in local development. The higher the self-reliance ratio, more advanced local development will be, so that economic growth can increase (Halim, 2002 in Sularso and Restianto, 2011). Ani and Dwirandra (2012) state that local financial performance in form of self-reliance ratios has a positive and significant effect on economic growth.

PAD, DAU, DAK, and DBH are part of local government financial resources. The government always increases PAD to implement local autonomy. It represents revenue from local government administration. The PAD increase must have an impact on local economy (Maryati and Endrawati, 2010). Indirectly, government should increase the potentials in their respective regions in order independent to do functions and impose financing for all local activities. Astuti (2015) proved that effective government financial performance has a positive effect on economic growth.

Efficiency is a comparison between output and input associated with predetermined performance standards or targets (Mardiasmo, 2002: 4). Efficiency is the relationship between goods and services (output) produced by an activity with resources used (Ardila, 2015). The local financial efficiency refers to a balance condition of output in form of realized capital expenditure or development expenditure and input in form of realized local income. Hamzah (2008) and Annisa (2011) showed that efficiency ratio has a significant and positive effect on economic growth.

The expenditure compatibility ratio illustrates how local governments prioritize their optimal allocation of funds for routine expenditure and development expenditure. Higher percentage of funds allocated for routine expenditures will decrease the percentage of investment expenditure to provide economic facilities and 
infrastructure for community (Halim, 2008). Based on above arguments, the hypothesis is formulated below.

H3 : Financial performance has a direct effect on economic growth

The self-reliance ratio illustrates the dependence of a region on external sources of funds. The self-reliance ratio also describes the level of community participation in local development. The higher the community participation will increase the self-reliance ratio, where there are sufficient funds available for capital expenditures allocation. Higher the self-reliance ratio will increase the local development and economic growth (Halim, 2002 in Sularso and Restianto, 2011). Ani and Dwirandra (2012) stated that local financial performance in form of self-reliance ratios has a positive and significant effect on economic growth.

The effectiveness ratio describes the ability of region to realize the planned PAD compared to target set based on real potential of the region. The region is effective to do its duties if the ratio is $1 \%$ or $100 \%$. Higher the effectiveness ratio shows better the local capability. The higher ability of regions to realize the targeted PAD will facilitate them to meet the needs for development expenditure to increase local economic growth (Sularso and Restianto, 2011). Utomo (2012) stated that Capital expenditure mediates the relationship between the PAD effectiveness and economic growth. This is consistent with Sularso and Restianto (2012).

The efficiency of local expenditure is based on the ratio between local revenue and total local expenditure. The efficiency ratio value below $100 \%$ means the region can reduce local expenditure efficiently with value of local expenditure being lower than local revenue in current year. Conversely, efficiency ratio above $100 \%$ indicates that APBD is less efficient where local government expenditure exceeds revenue. Ani and Dwirandra (2014) and Astuti (2015) found that efficiency of local expenditure directly affects the capital expenditures allocation, but does not affect economic growth. The effect of efficiency ratio is mediated by capital expenditure factor, in sense that achievement of APBD efficiency will affect local government policies in determining local expenditure allocations which then have an impact on rate of economic growth. Based on above arguments, hypothesis is developed below.

H4: Financial performance affects on economic growth through capital expenditures

\section{RESEARCH METHODS}

This is a quantitative descriptive study with aims to explain an empirical phenomenon accompanied by statistical data, characteristics and patterns of relationships between variables (Widarto, 2013). The research location is 10 local governments in North Maluku Province. The study population is the local government in North Maluku which consists of all local governments in province of North Maluku. The sample in study was the entire population sampled. There are 10 local governments in North Maluku Province, which means that sample used same as the number of local governments in North Maluku.

The data used type is secondary data form of District / City Government Financial Reports (LKPD) in North Maluku Province year 2016-2019, and non-financial data such as GRDP data. This research uses the Local Expenditure and Revenue Budget (APBD) data and Budget Realization Report (LRA) in Local Government Financial Report (LKPD), as well as the GRDP data in Economic Growth report of each Regency / City of North Maluku Province.

The method used to collect data is documentation, namely by collecting, recording, and reviewing secondary data in form of APBD Realization Report from Financial Audit Board (BPK) and Local Financial and Asset Management Agency of each District / City Province. North Maluku and GRDP data in Economic Growth obtained from Central Statistics Agency (BPS). The data obtained were then analyzed using Partial Least Square (PLS).

\section{RESULTS AND DISCUSSION}

North Maluku Province is youngest provinces that officially formed on 4 October 1999, with a legal umbrella under Law No. 46 of 1999 and Law no. 6 of 2003. North Maluku Province had its capital in Ternate at foot of Mount Gamalama for 11 years. During the 11 year period of transition and infrastructure preparation, capital of North Maluku Province was moved to Sofifi City in Halmahera Island, the largest island in North Maluku Province.

\section{Descriptive Statistics Test}

Descriptive statistics are used to determine the figure of each variable. The statistical results showed that observations in each study variable are 40 items. The table shows that financial performance variable has a minimum value of 0.43 and a maximum value of 1.58 with a mean value of 0.92 and standard deviation of 0.34 . The capital expenditure allocation variable has a minimum value of 0.63 and a maximum value of 3.20 with a mean value of 1.08 and a standard deviation of 0.48 . The economic growth variable has a minimum value of 3.61 and a maximum value of 27.04 with a mean value of 12.05 and a standard deviation of 7.96. 


\section{Goodness of Fit Testing}

This test is used to determine the ability of exogenous constructs (independent variables) in explaining the variations of endogenous constructs (dependent variable based on the R-square. The results of PLS Logarithm PLS process for R-square results are shown in Figure 1 and table 1 below.

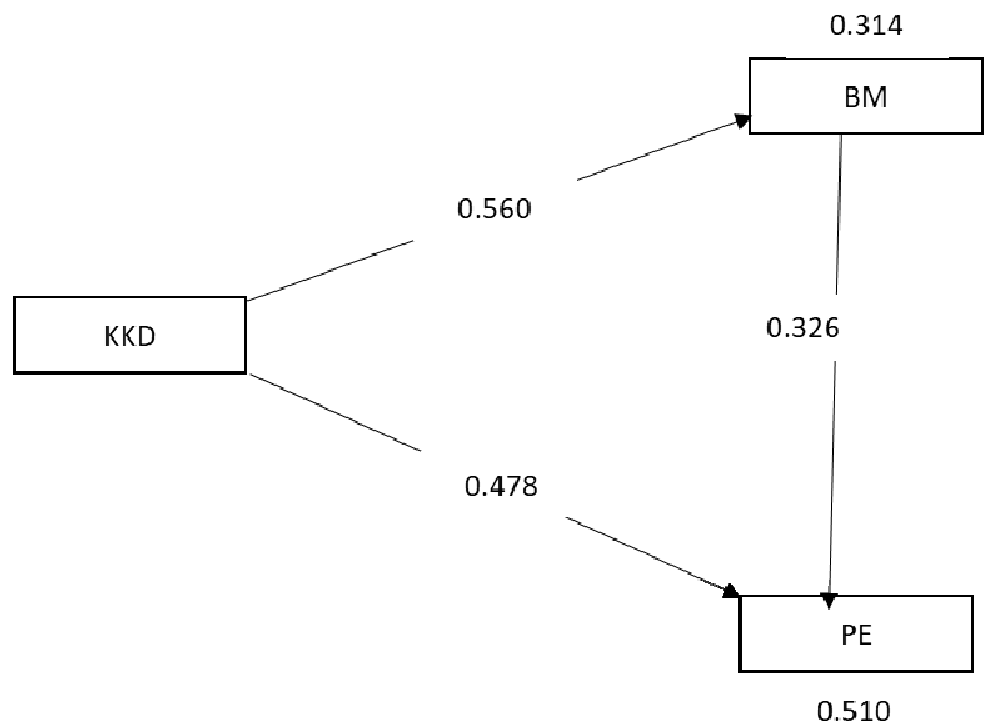

Description:

KKD: Local financial performance

BM: Capital expenditure

PE: Economy growth

Figure 1. Results of PLS Logarithm

Table 1. R-Square Test Results

\begin{tabular}{|l|l|l|}
\hline & R Square & R Square Adjusted \\
\hline BM & 0.314 & 0.299 \\
\hline PE & 0.510 & 0.489 \\
\hline
\end{tabular}

Source: Secondary Data Processed, 2021

Table 1 shows the R-Square test for the effect of financial performance on capital expenditures is 0.314. The influence of financial performance and capital expenditure on economy growth is 0.519 . It means the financial performance variable has an influence of $31.4 \%$ on capital expenditures allocation and remaining $68.6 \%$ is influenced by other variables outside of this study. Furthermore, the influence of financial performance variables and capital expenditures on economic growth is $51.9 \%$ and remaining $48.1 \%$ is influenced by variables outside of this study. Higher the R-Square value means greater the ability of independent variable to explain dependent variable.

\section{The Inner Model Evaluation}

This test aims to determine the relationship between exogenous constructs (independent variables) and endogenous (dependent variable). Inner model testing is executed by bootstrapping. The results of bootstrapping process with SMART-PLS software is shown in figure 2 . 


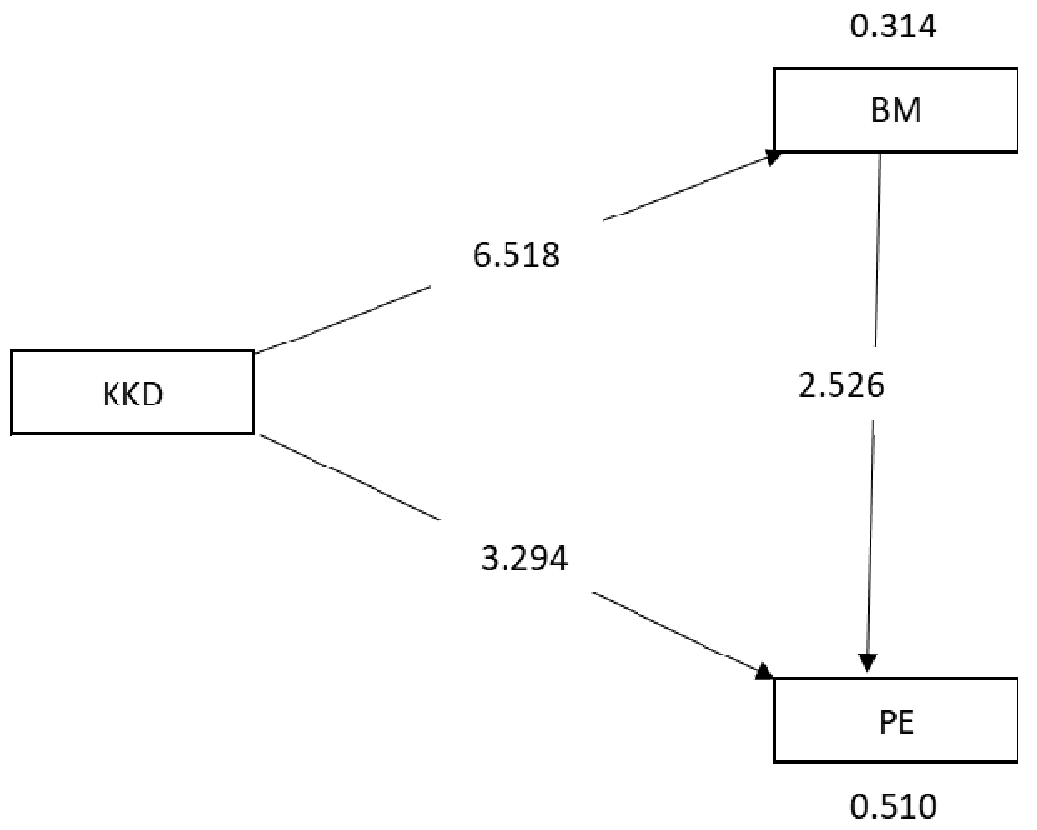

Figure 2. Result of Bootstrapping Process

\section{Hypothesis Test Results}

The next analysis after doing model analysis is hypothesis testing, this analysis is done by comparing the T-table value with T-statistics value generated from bootstrapping results in PLS. The hypothesis is accepted (supported) if the t-statistics value is higher than the t-table value (1.96) with a significance level of $5 \%$. The results of PLS bootstrapping process can be seen in table 2 .

Table 2. Hypothesis Test Results

\begin{tabular}{|l|l|l|l|l|l|}
\hline & Original Sample & Sample Mean & Standard Deviation & T Statistics & P Values \\
\hline $\mathrm{BM} \rightarrow \mathrm{PE}$ & 0.326 & 0.337 & 0.129 & 2,526 & $\mathbf{0 . 0 1 2}$ \\
\hline $\mathrm{KKD} \rightarrow \mathrm{BM}$ & 0.560 & 0.562 & 0.086 & 6,518 & $\mathbf{0 . 0 0 0}$ \\
\hline $\mathrm{KKD} \rightarrow \mathrm{PE}$ & 0.478 & 0.462 & 0.145 & 3,294 & $\mathbf{0 . 0 0 1}$ \\
\hline $\mathrm{KKD} \rightarrow \mathrm{BM} \rightarrow \mathrm{PE}$ & 0.183 & 0.193 & 0.089 & 2,049 & $\mathbf{0 . 0 4 1}$ \\
\hline
\end{tabular}

Source: Processed Secondary Data, 2021

Description:

KKD: Local financial performance

BM: Capital expenditure

PE: Economy growth

Based on table 2, the hypotheses tests can be explained below.

\section{Hypothesis H1}

Hypothesis H1 stated that financial performance affects on capital expenditure. Tabel 2 shows the path coefficient of financial performance on economic growth has a coefficient of 0.326 with a positive direction. This means that higher the financial performance will increase the capital expenditures allocation. The analysis results show that $t$ value is $2.526>1.960$ with a significance of $0.012>0.05$. This shows that financial performance has an effect on capital expenditures allocation, therefore hypothesis $\mathrm{H} 1$ accepted.

The research results are explained by signal theory. The information asymmetry between local government and society can be reduced by providing good signals in form of convincing financial reports (Adiputra, et al 2018). Artana (2016) stated that Signaling theory is also used to explain that government is the party that is given the mandate and people as the trustee. The financial statement auditor is a third party who audits financial reports to provide reliable and relevant information trusted by trustee.

This study results are consistent with Asepma et al (2015) that financial performance of districts / cities in the province directly has an influence on capital expenditures allocation. Gerungan et al. (2015) also found that simultaneously the variables of local financial independence, local financial dependence, PAD effectiveness, 
capital expenditure effectiveness, efficiency, and consistent expenditure have a significant effect on capital expenditures.

\section{Hypothesis $\mathrm{H} 2$}

Hypothesis $\mathrm{H} 2$ stated that Capital expenditure affects on economic growth. Table 2 shows that the $\mathrm{t}$ value of $6.518>1.960$ with a significance of $0.000<0.05$. The coefficient value of 0.560 and having a positive direction. It means that higher the capital expenditures allocation will increase the economic growth, therefore, hypothesis $\mathrm{H} 2$ is accepted.

Abdul Halim (2014) stated that capital expenditure is a local government expenditure with benefits exceed one fiscal year and will add assets or local wealth, and then add routine expenditures, such as operating costs and maintenance costs. The capital expenditure budget, especially infrastructure, is highly dependent on input from engineers, architects and planners. Capital expenditures generally come from grants and capital expenditure budgets for several budget years (Bland and Nunn, 1992).

These study findings also support Kuncoro (2004) that development of facilities and infrastructure by local governments has a positive effect on economic growth. Todaro (2003: 92) in Sasana (2009) stated that there are three factors in economic growth of each country, namely capital accumulation, population growth and technological progress.

\section{Hypothesis $\mathrm{H3}$}

Hypothesis H3 stated financial performance has a direct effect on economic growth. Table 2 shows that path coefficient of financial performance on economic growth is 0.478 with positive direction. It means that higher financial performance will increase the economic growth. Hypothesis test results show that financial performance with economic growth has a t value of 3.294> 1.960 with a significance $0.001<0.05$. This shows that financial performance has a direct effect on economic growth, therefore, hypothesis $\mathrm{H} 3$ is accepted.

The higher independence ratio will increase the local development and economic growth (Halim, 2014). Therefore, local financial management can be implemented by output performance orientation, using the concept of value for money and principles of good governance (Halim, 2007: 24) with a hope to achieve high economic growth

The theory of fiscal federalism states that economic growth can be achieved in fiscal decentralization through the implementation of local autonomy. This theory explains how fiscal decentralization affects local government behavior. Penthury in Ani and Dwirandra (2014) stated that local governments must be able to provide good public service facilities for all local communities, because infrastructure is the key to increase the economic growth.

This study results are consistent with Ani and Dwirandra (2012) that local financial performance in form of self-reliance ratios has a positive and significant effect on economic growth. PAD, DAU, DAK, and DBH are part of local government financial resources. In relation to implementation of local autonomy, government always increases PAD. It represents revenue from the local efforts to finance local government administration. The PAD increase must have an impact on local economy (Maryati and Endrawati, 2010). Indirectly, government should increase the potentials in their respective regions to become independent to do functions and impose financing for all local activities.

Astuti (2015) proved that effective government financial performance has a positive effect on economic growth. The expenditure compatibility ratio illustrates how local governments prioritize their optimal allocation of funds for routine expenditure and development expenditure. The higher the percentage of funds allocated for routine expenditure means smaller percentage of investment expenditure to provide economic facilities and infrastructure for community (Halim, 2014).

\section{Hypothesis $\mathrm{H} 4$}

Hypothesis 4 stated financial performance affects on economic growth through capital expenditures. Table 2 shows that the coefficient value is 0.183 and $t$ value is $2.049>t$ table (1.960) and significance value of 0.041 $<0.05$. It means indirectly financial performance affect on economic growth through the capital expenditures allocation. Therefore, Hypothesis $\mathrm{H} 4$ is accepted.

This study results consistent with Utomo (2012) that capital expenditures mediate the relationship between the PAD effectiveness and economic growth. Todaro (2003) showed three factors in economic growth, namely capital accumulation, population growth and technological advances. The capital expenditures allocation is also influenced by the local financial performance, such as decentralization, financial dependence level, financial independence, and PAD effectiveness (Prihastuti, et.al, 2015).

Economic growth encourages local governments to carry out economic development by managing existing resources and forming a partnership pattern with community to create new jobs that will affect the development of local economic activity. This economic development is marked by higher per capita income of population and 
welfare improvement (Kuncoro, 2004). The theory of fiscal federalism states that for certain public goods or services, such as local public goods, decentralization can increase the efficiency and accountability of resource allocation.

\section{CONCLUSIONS AND SUGGESTIONS}

Based on analysis results and discussion, the conclusion can be stated below.

1. Financial performance affects on capital expenditures allocation in districts / cities of North Maluku Province.

2. Financial performance affects on economic growth in districts / cities of North Maluku Province.

3. Capital expenditures affect on economic growth in districts / cities of North Maluku Province.

4. The financial performance affect on economy growth in district / city in North Maluku province.

Based on the conclusion, Regency / City Government in North Maluku Province should increase the capital expenditures allocation to improve the economic growth. District and City Governments in North Maluku Province should boost the rate of local economic growth. The local authority should regulate the local expenditure in accordance with aspirations of community

The future researcher should conduct research by increasing the number of samples, namely by adding the research year so that research results can be generalized more broadly. In addition, future researchers can develop and use other variables related to economic growth and capital expenditures such as general allocation fund, special allocation funds and revenue-sharing.

\section{REFERENCES}

Adiputra, I. M. P., Utama, S., \& Rossieta, H. (2018). Transparency of local government in Indonesia. Asian Journal of Accounting Research.

Artana, M. B., Herawati, N. T., AK, S., Atmadja, A. T., \& SE, A. (2014). Pengaruh Kecerdasan Intelektual (IQ), Kecerdasan Emosional (EQ), Kecerdasan Spiritual (SQ), dan Perilaku Belajar Terhadap Pemahaman. JIMAT (Jurnal Ilmiah Mahasiswa Akuntansi) Undiksha, 2(1).

Bisma, I., \& Susanto, H. (2010). Evaluasi kinerja keuangan daerah pemerintah Provinsi Nusa Tenggara Barat tahun anggaran 2003-2007. Ganec Swara, 4(3), 75-86.

Bland, R. L., \& Nunn, S. (1992). The impact of capital spending on municipal operating budgets. Public Budgeting \& Finance, 12(2), 32-47.

Ghozali, Imam. 2018. Aplikasi Analisis Multivariate dengan Program IBM SPSS 25. Badan Penerbit Universitas Diponegoro: Semarang

Halim, A., \& Kusufi, M. S. (2014). Teori, Konsep, dan Aplikasi Akuntansi Sektor Publik. Jakarta: Salemba Empat.

Indonesia, P. R. (2004). Undang-undang Republik Indonesia Nomor 1 tahun 2004 tentang Perbendaharaan Negara.

Havid Sularso (2011). Pengaruh Kinerja Keuangan Terhadap Alokasi Belanja Modal dan Pertumbuhan Ekonomi Kabupaten/Kota di Jawa Tengah. Media Riset Akuntansi,Vol. 1 No. 2, 109-124.

Fathah, R. N. (2017). Analisis Rasio Keuangan untuk Penilaian Kinerja pada Pemerintah Daerah Kabupaten Gunung Kidul. Ebbank, 8(1), 33-48. http://ebbank.stiebbank.ac.id/index.php/ ebbank/article/view/109.

Kaeng, A. R. (2015). Analisis Pendapatan Asli Daerah Untuk Belanja Daerah Pada Pemerintah Kota Tomohon. Jurnal Riset Ekonomi, Manajemen, Bisnis Dan Akuntansi, 3(2), 958-965.

Keuangan, D. S. A. (2007). Standar Akuntansi Keuangan. Salemba Empat. Jakarta.

Mahmudi. (2010). Analisis Laporan Keuangan Pemerintah Daerah-Panduan Bagi Eksekutif, DPRD, dan Masyarakat dalam Pengambilan Keputusan Ekonomi, Sosial, dan Politik. Yogyakarta: UPP STIM YKPN.

Mardiasmo, D., \& MBA, A. (2009). Akuntansi Sektor Publik. Yogyakarta: ANDI

Muhibtari, Astriana Nabila. (2014). Analisis Rasio Keuangan Anggaran Pendapatan dan Belanja Daerah Kota Magelang untuk Menilai Kinerja Keuangan Pemerintah Daerah Kota Magelang Tahun Anggaran 20082012. Skripsi. Universitas Negeri Yogyakarta.

Pemerintahan, K. S. A. (2010). Peraturan Pemerintah Republik Indonesia Nomor 71 Tahun 2010 Tentang Standar Akuntansi Pemerintahan. Jakarta: Penerbit Salemba Empat.

Pramono, J. (2014). Analisis Rasio Keuangan Untuk Menilai Kinerja Keuangan Pemerintah Daerah. Jurnal Ilmiah Among Makarti, 7, 83-112.

Pratiwi, N. M. (2017). Evaluasi Kinerja dan Kemampuan Keuangan Daerah Pada Dinas Pendapatan Pengelolaan Keuangan dan Aset (DPPKA) Daerah Istimewa Yogyakarta. Eprints.Uny.Ac.Id. https://doi.org/10.1017/CBO9781107415324.004

Riduwan, dan Engkos Achmad Kuncoro. 2017. Cara Menggunakan dan Memakai Path Analysis (Analisis Jalur). Bandung: Alfabeta

Sasana, H. (2009). Analisis Dampak Pertumbuhan Ekonomi, Kesenjangan Antar Daerah Dan Tenaga Kerja Terserap Terhadap Kesejahteraan Di Kabupaten/Kota Provinsi Jawa Tengah Dalam Era Desentralisasi 
Fiskal. Jurnal Bisnis dan Ekonomi, 16(01).

Sekaran, Uma dan Roger Bougie, (2017), Metode Penelitian untuk Bisnis: Pendekatan Pengembangan-Keahlian, Edisi 6, Buku 2, Salemba Empat, Jakarta Selatan 12610.

Sibua, N., \& Pribadi, F. (2019). Analisis Kinerja Pengelolaan Keuangan Pemerintah Daerah Kabupaten Pulau Morotai Provinsi Maluku Utara (Studi Pemerintah Kabupaten Pulau Morotai Lima Tahun Terakhir 20112015). INOBIS: Jurnal Inovasi Bisnis dan Manajemen Indonesia, 2(3), 343-357.

Sijabat, Mentari Yosephen, Choirul Shaleh dan Abdul Wachid. (2013). "Analisis Kinerja Keuangan Serta Kemampuan Keuangan Pemerintah Daerah dalam Pelaksanaan Otonomi Daerah". Jurnal Administrasi Publik (JAP) Vol. 2 No. 2. Hlm. 236-242

Sukmadinata, Nana Syaodih. (2015). Metode Penelitian Pendidikan. Bandung: PT Remaja Rosdakarya Offset.

Sularso, H., \& Restianto, Y. E. (2012). Pengaruh kinerja keuangan terhadap alokasi belanja modal dan pertumbuhan ekonomi kabupaten/kota di Jawa Tengah. Media Riset Akuntansi, 1(2).

Sumarjo, Hendro. (2010). Pengaruh Karakteristik Pemerintah Daerah Terhadap Kinerja Keuangan Pemerintah Daerah. Skripsi. Fakultas Ekonomi Universitas Sebelas Maret

Syamsi, Ibnu. (1986). Pokok-Pokok Kebijaksanaan, Perencanaan, Pemrograman, dan Penganggaran Pembangunan Tingkat Nasional dan Regional. Jakarta: CV Rajawali

Ulum, Ihyahul. (2009). Audit Sektor Publik. Jakarta: PT Bumi Aksara 